\title{
Nanocystalline silicon solar cells
}

\author{
J.K. Rath
}

Received: 27 June 2008 / Accepted: 4 November 2008 / Published online: 23 December 2008

(C) The Author(s) 2008. This article is published with open access at Springerlink.com

\begin{abstract}
Nanocrystalline silicon material has made rapid progress in the last several years and at present it can be defined as real device quality as a photoactive layer for solar cells. A number of innovative ideas, such as the deposition at the crystalline to amorphous transition, at high pressure depletion condition, by taming of the ion energy, by grading of the material growth, at reduced unwanted dopant incorporation, have helped to reach an efficiency of $10 \%$ for single junction nanocrystalline silicon cells. In situ plasma and gas phase diagnosis have contributed to the fast optimisation of deposition process parameters. Deposition rate, open circuit voltage and light confinement are some of most critical issues that are currently pursued. Materials with a defect density as low as $10^{15} \mathrm{~cm}^{-3}$ have been made, however, they are still not good enough for $n-p$ junctions; the device structure is still of drift type in a $\mathrm{p}-\mathrm{i}-\mathrm{n}$ or $\mathrm{n}-\mathrm{i}-\mathrm{p}$ configuration.
\end{abstract}

PACS 84.60.Jt $\cdot 73.63 . \mathrm{Bd} \cdot 81.15 . \mathrm{Gh} \cdot 73.00 .00 \cdot 68.35 . \mathrm{bg}$

\section{Introduction}

For the last several years the photovoltaic market is growing at an average of $40 \%$ [1]. Both bulk silicon ( $\mathrm{Si}$ ) and thin films have increased their markets; however, the share of thin film silicon has actually fallen and it is at present around $7 \%$. The efforts towards thinner wafers especially for heterojunction with intrinsic thin layer (HIT) type of cells shown by Sanyo Co. (Japan) for thicknesses down to $70 \mu \mathrm{m}$

J.K. Rath $(\bowtie)$

Faculty of Science, Debye Institute for Nanomaterials Science,

Nanophotonics-Physics of Devices, Utrecht University,

P.O. Box: 80000, 3508 TA Utrecht, The Netherlands

e-mail: J.K.Rath@uu.nl
[2] and thin cells $(50 \mu \mathrm{m})$ by transfer technology [3] and the progress in ribbon type silicon technology [4] are going to take away some of the advantages of thin film based solar cells as far as the material cost is concerned. On the other hand, thin film silicon solar cells have to also compete with other types of thin film materials such as $\mathrm{CdTe}$ and $\mathrm{CuInS}_{2}$ (CIS). The recent reports from First Solar (US) indicate that their CdTe based modules reach manufacturing costs of $\$ 1.25 / \mathrm{Wp}$ [5] and a claimed energy payback time of 1.1 years. Their expansion to Europe (120 MW at Frankfurt (Oder), Germany) puts a challenge to other thin film technology based productions in Europe. CIS technology has brought in new players such as Honda motors (Japan) [6]. Moreover, except for CSG solar [7], all other industries want to use cells based on nanocrystalline silicon (nc-Si) in combination with amorphous silicon (a-Si) in a tandem (so-called "micromorph") or triple junction concept (Kaneka Co. [8], Sharp Co. [9], Unisolar Co. [10]) to achieve high stable efficiencies.

After the initial excitement over the success of the Neuchatel group on these new high efficiency cells [11], a great deal of discussion concerning the real superiority of the so called "micromorph" tandem a-Si/nc-Si cell in comparison with the complete amorphous type tandem cells containing silicon germanium has taken place. This has predominantly arisen due to the rather thick bottom cells used in micromorph devices and due to the efficiency of nanocrystalline cells to decrease monotonically with increase in deposition rate [12]. A related problem, of course, arises that, in these high current generating cells, top cells also become thicker. This means, we have to deal with two issues. The first and most important one is the deposition rate of the bottom cell (nanocrystalline cell). In combination with a high deposition rate stable protocrystalline silicon top cell in a 


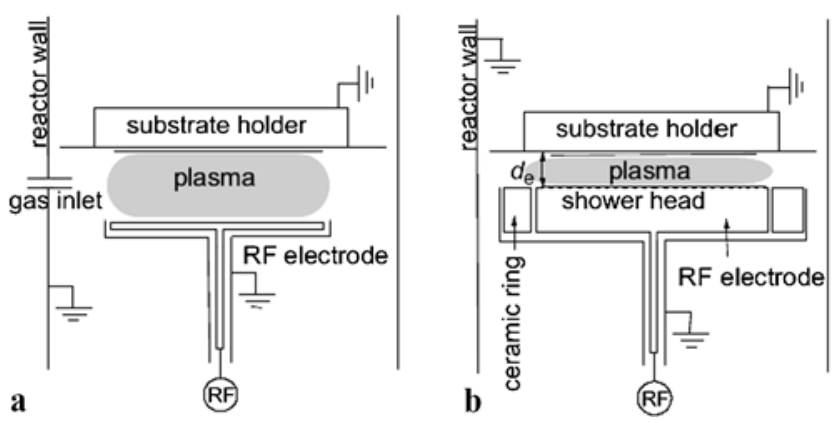

Fig. 1 The RF electrodes used for amorphous (a) and nanocrystalline (b) depositions in ASTER

multijunction approach, high efficiency thin film silicon solar cells with an industrial edge over the other types of solar cells can be expected.

\section{Deposition process}

Depositions of nc-Si layers are made in ultra high vacuum (UHV) deposition systems with chemical vapour deposition (CVD) techniques. Figure 1 shows the UHV multichamber system called ASTER [13] used in Utrecht University (UU) that has four process chambers. Two types of electrodes are employed to deposit a-Si and nc-Si materials, respectively, for depositions by very high frequency plasma enhanced chemical vapour deposition (VHF PECVD). Electrode A that has a fixed inter-electrode distance of $27 \mathrm{~mm}$ is used for the deposition of a-Si layers for the implementation in the top cell of the tandem structure. The frequency of RF power for this case is variable up to $100 \mathrm{MHz}$ and maximum power that can be delivered is $100 \mathrm{~W}$. The electrode B that is used for nc-Si layer deposition can have variable position and the distance between the electrodes can be made rather small (down to $5 \mathrm{~mm}$ ) to adapt to the high process pressure conditions. The power up to $1000 \mathrm{~W}$ from an RF generator with a frequency $60 \mathrm{MHz}$ is fed to the electrode B. The nc$\mathrm{Si}$ i-layers are made with a moderate hydrogen dilution of silane gas, expressed as $d_{\mathrm{H}}=\mathrm{fH}_{2} / \mathrm{fSiH}_{4}$ that delivers material at the transition of nc-Si to a-Si.

The deposition of nc-Si needs a careful in situ monitoring because of the sensitivity to the plasma conditions at the transition regime of growth. The monitoring is done basically at three stages: (i) the delivered power to the electrode, (ii) the plasma and gas phase condition, and (iii) the material growth. In ASTER, a voltage-current (V-I) probe is used in the VHF PECVD reactors for the measurement of the actual delivered power to the discharge. This is much more accurate compared to the traditional method of monitoring the reflected power at the generator since it is not affected by power lost in the cables and matching network. Furthermore, from the recorded data, the resistivity of the plasma can be calculated, which is an indicator for particle formation and dust generation in the reactor. The optical emission of the plasma (due to transitions from excited states of radicals that are formed due to electron impact reactions) is detected through a quartz window view port. With optical emission spectroscopy (OES) [14], intensities of the $\mathrm{Si}^{*}$ line (289 nm) and the Balmer alpha $\left(\mathrm{H}_{\alpha}\right)$ line $(656 \mathrm{~nm})$ are recorded and analysed. Mass spectrometer with quadrupole analyser [15] and electrostatic retarding field ion energy analyser [16] are used to probe the ion energy distribution function (IEDF). To monitor growth process and quality of the grown material a UV-VIS spectroscopic ellipsometer is used [17].

\section{High efficiency nc-Si cell at high growth rates}

The success of nc-Si solar cells can be attributed to identifying the proper regimes of growth which for PECVD has basically two components as described below.

\subsection{Control of ion energy and depletion condition}

This is achieved by depositing at high frequency of RF power and/or high pressures. This is especially critical for depositions at high rates. A deposition regime called high pressure depletion (HPD) [18] shows how this can be achieved. However, increasing pressure to deposit at high rate needs adjustment to the growth process in such a way as to keep the residence time of species in gas phase short enough to avoid higher radicals or dust formation.

\section{High rate deposition regime}

In a PECVD process, the deposition rate of a-Si and also $\mathrm{nc}-\mathrm{Si}$ is a function of electron density in the plasma. Application of high frequency is one of the ways to increase the electron density and hence the deposition rate [19].

At UU, a deposition process in the HPD regime combined with VHF PECVD and shower head for gas distribution in the plasma zone has been used. A number of deposition parameters (such as pressure, power and gas flow rate) have to be adjusted to achieve device quality nc-Si at high deposition rates [20] and for this the quality control of the silicon material is very crucial. An optimisation method based on in situ plasma diagnosis (without going for actual long depositions) is as follows. Figure 2(a) shows that at each applied power the $\mathrm{Si}^{*}$ intensity increases linearly with increasing the silane flow ( $d_{\mathrm{H}}$ is kept constant at 28), which is an indication that silane is highly depleted. Figure 2(b) shows the dependence of the $\mathrm{H}_{\alpha} / \mathrm{Si}^{*}$ ratio with the silane flow rate for a series of increasing powers. It can be observed that at each power the increase of silane flow leads to a decreasing $\mathrm{H}_{\alpha} / \mathrm{Si}^{*}$ ratio, which is attributed to the loss 


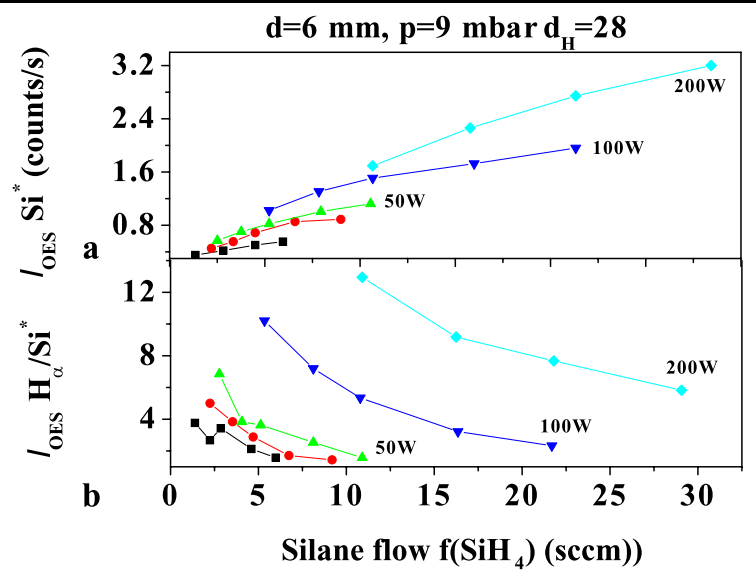

Fig. 2 Dependence of the (a) intensity $\mathrm{Si}^{*}$ and (b) intensity ratio $\left(\mathrm{H}_{\alpha} / \mathrm{Si}^{*}\right)$ on the RF power and gas flow rate [20]

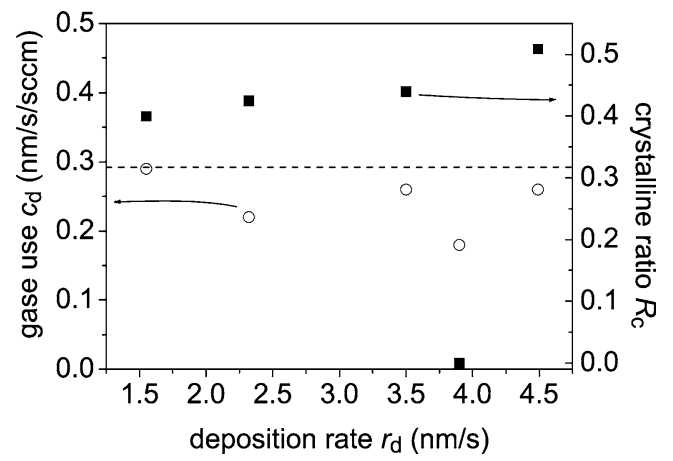

Fig. 3 Correlation between gas use and the crystalline ratio in a nanocrystalline silicon material at various deposition rates. The case of a material with a low gas use at $3.9 \mathrm{~nm} / \mathrm{s}$ has a drastic effect on the crystallinity in the material [20]

of hydrogen due to abstraction reaction with the silane gas in the gas phase. Hence, following the trend from Fig. 2(a), if we simply increase the silane gas flow keeping the dilution constant, we will end up with amorphous silicon due to the lowering of the $\mathrm{H}_{\alpha} / \mathrm{Si}^{*}$ ratio. It is seen from Fig. 2 that the power has to be proportionally increased to maintain the $\mathrm{H}_{\alpha} / \mathrm{Si}^{*}$ ratio. The key parameter here is to maintain the depletion. In addition, we have introduced a new parameter (described below) which gives a better control of the depletion condition.

\section{Depletion condition}

It is observed that as the deposition rate is increased (increasing the power and total gas flow (keeping the $d_{\mathrm{H}}$ constant), maintaining this $\mathrm{H}_{\alpha} / \mathrm{Si}^{*}$ ratio is itself not sufficient to achieve the desired crystallinity. Hence, another technique is introduced to accurately find a parameter to describe the optimum deposition condition. We call this parameter the "gas utilisation parameter" [20], defined as $c_{\mathrm{d}}=$ deposition rate/silane gas flow rate, which basically is a measure for

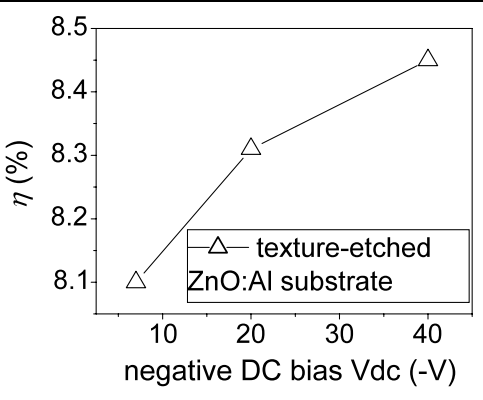

Fig. 4 Dependence of external dc bias during deposition on the efficiency of a pin nanocrystalline silicon solar cell [22]

the depletion condition. It is observed that by just increasing power and gas flow in same proportion it is not always possible to maintain the same depletion condition (especially at high power regimes) and the $c_{\mathrm{d}}$ is reduced. The case of a material with a low gas use at $3.9 \mathrm{~nm} / \mathrm{s}$ has a drastic effect on the crystallinity in the material (Fig. 3). By adjusting the total flow rate, the depletion can be maintained at a desired level (which is estimated in this case to be $0.29 \mathrm{~nm} / \mathrm{s} / \mathrm{sccm}$ ) and the required crystalline fraction is restored. For the deposition at $200 \mathrm{~W}$ and $400 \mathrm{~W}$ this method of adjusting the flow was employed to maintain the desired depletion, and nc-Si materials with device quality even up to a deposition rate of $4.5 \mathrm{~nm} / \mathrm{s}$ were produced. The quality of the best ncSi layer at $0.45 \mathrm{~nm} / \mathrm{s}$ was confirmed from the low defect density in the order of $10^{14} \mathrm{~cm}^{-3}$ [21] measured by Fourier transform photocurrent spectroscopy (FTPS). However, the defect density was found to increase with an increase of the deposition rate, increasing by an order at $4.5 \mathrm{~nm} / \mathrm{s}$.

\section{External bias}

An adaptation to the standard deposition at high pressure depletion condition by an application of an external bias to the cathode effectively reduces the plasma potential and the ion energies, without changing the gas phase chemistry significantly [22] as monitored by $\mathrm{Si}^{*} / \mathrm{H}_{\alpha}$ ratio (that has a strong correlation with the growth kinetics). Figure 4 shows the dependence of the efficiency of a $\mathrm{p}-\mathrm{i}-\mathrm{n}$ nc-Si solar cell with the amount of external dc bias to the cathode. The fill factor (FF) also follows this trend. From FTPS measurements on real solar cells, it was clearly observed that the defect density systematically decreased [21] with an increase of the (negative) external bias voltage to the cathode during deposition. A reduction by a factor of 2 in defect density is obtained by applying a voltage of $20 \mathrm{~V}$.

\subsection{Transition type material}

Materials made at the transition to amorphous growth show the best electronic quality. In the initial development phase of nc-Si cells [11], materials with very high crystallinity 
were considered to be ideal for the devices. In 1998, the author proposed that nc-Si can be made in different regimes, and two specific regimes of growth had been identified as important for device performance [23]. These two types were named as Poly 1 and Poly2. Whereas the material made at high hydrogen dilution is completely crystalline with no noticeable amorphous incubation phase, it is very defective and porous, characterised by the typical $2100 \mathrm{~cm}^{-1}$ mode of vibration in the IR spectrum and this material goes through fast post deposition oxidation (becomes n-type). On the other hand, the films made at low hydrogen dilution have the characteristics of a compact structure, and hydrogen atoms in the film are at compact sites [24] $\left(2000 \mathrm{~cm}^{-1}\right.$ in IR spectrum [25]). These sorts of materials showed the device quality, but suffered from amorphous incubation phase, being in a deposition regime near to the amorphous transition regime [26]. A further reduction in hydrogen dilution basically leads to an amorphous matrix with crystalline islands dispersed in it. Thus, a profiled layer deposition was proposed, which delivered first working nc-Si cell by hot wire CVD (HWCVD). Subsequently, it was established by the Julich group [27] and then by others [22, 28] that indeed a transition type material made at nanocrystalline to amorphous transition delivers the best cell performance.

Monitoring of the transition phase regime has been made by predominantly two ways. The ratio $\mathrm{H}_{\alpha} / \mathrm{Si}^{*}$ in the emission spectrum of the plasma is a fingerprint of the phase of the deposition [15] and the amorphous to crystalline transition can be monitored by this ratio.

However, the real test lies in monitoring the crystalline fraction $\left(R_{\mathrm{c}}\right)$ of the material by Raman spectroscopy. It has been observed that the crystalline component is a major deciding factor for the photosensitivity of the material. The best cell performance is obtained at $R_{\mathrm{c}}$ of $\sim 0.4$ [29]. Therefore, this quantity is meticulously maintained in the material when comparing the behaviour of solar cells with i-layers made at different deposition conditions. The Raman spectra are measured at the front and the back side of the nc-Si films deposited on glass to know the evolution of the crystallinity in the growth direction. For the case of a complete solar cell, this method, though not very accurate owing to the influence of the doped layers, is very helpful for the quality control of the i-layer in the cell. A stepwise etching of the doped layer and the intrinsic layer by $\mathrm{KOH}$ solution is some times used to probe the crystallinity at different depths [30].

\section{Structural evolution}

The nanocrystalline material normally grows in an inhomogeneous way, i.e. incubation, nucleation and then conical growth to a full crystalline region after some thickness. A linear grading of hydrogen dilution to make a profiled layer is used to retard the development of the crystallinity in the

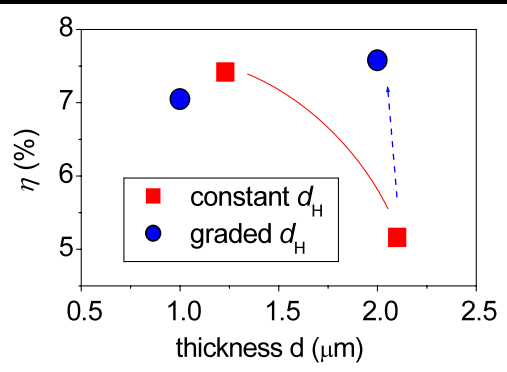

Fig. 5 Thickness dependence of solar cell efficiency (average best 10) for i-layers deposited with a constant as well as a parabolic graded hydrogen dilution [22]

growth direction. However, this method is not entirely accurate. At constant hydrogen dilution, due to conical growth of grain columns, there is a quadratic increase of the crystallinity with an increase of thickness. By employing a parabolic type of grading where the hydrogen dilution is reduced step wise to maintain the crystallinity at a constant level, a more homogeneous growth of the i-layer can be made, as confirmed by comparing the Raman spectra obtained from the top (n) and bottom (p) side of the nanocrystalline silicon cell [29]. The efficiencies of the $\mathrm{p}-\mathrm{i}-\mathrm{n} \mathrm{nc}-\mathrm{Si}$ solar cells with and without parabolic grading are shown in Fig. 5.

\section{Solar cells}

Three groups in Europe, namely Utrecht University, FZ Julich and IMT (Univ. Neuchatel), have achieved near 10\% efficiency for nc-Si cells in $\mathrm{p}-\mathrm{i}-\mathrm{n}$ configuration. FZ Julich has the highest initial efficiency of $10.3 \%$ [30], whereas Utrecht University has reported the highest stabilised efficiency of $10 \%$ [29]. However, the best efficiencies in $\mathrm{n}-\mathrm{i}-\mathrm{p}$ configuration reported by Canon Co. and Kaneka Co with comparable values are even higher than that of the $\mathrm{p}-\mathrm{i}-\mathrm{n}$ cells (Fig. 6). Moreover, a nanocrystalline silicon $\mathrm{p}-\mathrm{i}-\mathrm{n}$ cell with stabilised efficiency of $6.7 \%$ has been achieved at a high deposition rate of $4.5 \mathrm{~nm} / \mathrm{s}$ [20], and this cell shows a particularly interesting behaviour in the sense that the efficiency actually improves with light soaking (initial efficiency of $6.4 \%$ rises to $6.7 \%$ with light soaking). This makes these types of cells very useful as current limiting cells of a tandem cell. In addition, this effect makes the choice of the top cell more flexible (if the tandem cell is bottom cell limiting).

\subsection{Open circuit voltage}

The open circuit voltage has found the central place in the development of nc-Si i-layer for solar cells. Because of the large difference in the voltage between an a-Si cell and an 


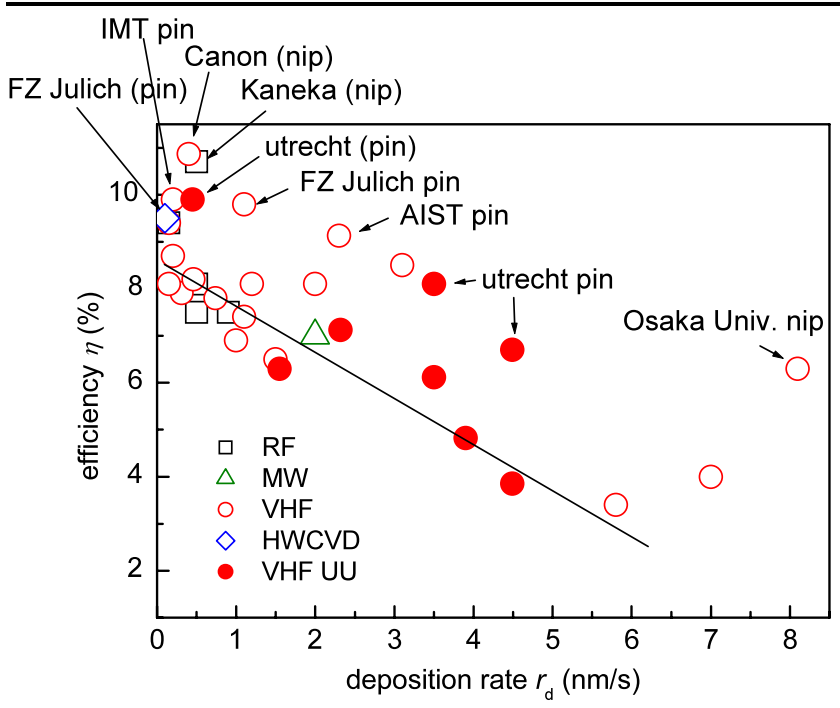

Fig. 6 Record efficiency values of single junction nc-Si cells at various deposition rates

nc-Si cell, it is easy to identify which type of i-layer it is [28]. Moreover, the open circuit voltage has been found to be a continuous function of the average crystalline fraction in the film [31]. This has been effectively used to monitor the phase of a nanocrystalline material, especially to identify the so-called transition regime which has a Raman crystalline ratio of $\sim 40-50 \%$.

A c-Si cell can reach a Voc of $0.7 \mathrm{~V}$. The biggest reduction of the efficiency in a polysilicon cell compared to a single crystalline cell is manifested by its Voc which is sensitive to the grain size. The grain boundary defects are considered to be a deciding factor for this and a monotonic decrease of Voc with an increase in grain boundary defects or a decrease in grain size has been reported [32]. This correlation which is valid for the polycrystalline materials containing only crystalline grains and grain boundaries can be simulated. From this consideration, the nanocrystalline silicon cells (with grain size typically $\sim 20 \mathrm{~nm}$ ) are expected to show very low Voc values. However, the nc-Si cells made at low temperature $\left(<200^{\circ} \mathrm{C}\right)$ deviate from the above trend and show Voc values that are comparable to the big grain size poly-Si cells. This has been attributed to the passivation of the grain boundaries that occurs by hydrogen termination of the grain boundary dangling bond defects during deposition, just as in the case of post hydrogen passivation used for the poly-Si cells. However, the presence of a second phase, amorphous silicon, is also considered as an equally probable cause for the passivation. The support to this reasoning comes from the characteristics of heterojunction cells (the so called HIT cells), where an amorphous silicon layer has been used as a passivation layer and this results in a voltage of more than $0.72 \mathrm{~V}$ [33]. Another support to this hypothesis comes from the fact that the voltage increases monotonically with the amorphous content in the film and reaches a high value for a transition material, in which case there is $\sim 50 \%$ amorphous phase and there is a high probability that grain-boundary surfaces are conformally covered with the amorphous passivating layer. One can then predict that the optimisation of the grain boundary passivation will follow the same route as the HIT cells, in which case the temperature of the deposition is crucial and a temperature lower than $150^{\circ} \mathrm{C}$ may be more beneficial for the passivation. However, a trade-off between the low temperature induced defect creation and better passivation at low temperature has to be made.

The open circuit voltage can also be increased by a $\mathrm{p} / \mathrm{i}$ interface treatment [34] or inserting an amorphous silicon buffer layer between the p-layer and the i-layer. This improvement could be due to protection of the $\mathrm{p} / \mathrm{i}$ interface region and reduced recombination. The role of the i-layer on the p/i interface states and the resultant Voc is inferred from the type of deposition used for the i-layers. For example, both Utrecht University and FZ Julich groups presented in 2002 that a nanocrystalline silicon with i-layer made by HWCVD can deliver high Voc, and Voc values of $0.58 \mathrm{~V}$ [35] and $0.57 \mathrm{~V}$ [36] were reported by these two groups, respectively. One may tempt to correlate this high Voc to a soft deposition because in HWCVD one does not expect any ion bombardment at the growing surface. Later, this characteristic of the HWCVD layer was used by the Julich group as buffer layer between $p$ and $i$ in their nc-Si cell made mainly by VHFPECVD. A similar high Voc of $\sim 0.57 \mathrm{~V}$ [30] has been achieved. Though it is possible to get high initial efficiencies by using buffer layers, the contribution of the buffer layer to the light induced degradation behaviour of the nc-Si cell has not been studied. In the case of amorphous silicon cells, buffer layers are known to affect the stability of the cells. It has to be noted that the nanocrystalline silicon cell without using any buffer layer showed absolutely no degradation under light soaking and a stable efficiency of $10 \%$ has been achieved in that case [37]. This cell has a moderate $\mathrm{Voc}$ of $0.52 \mathrm{~V}$, but enjoys a high stabilised efficiency. It may be necessary to find a suitable buffer layer that acts as a good passivation layer at the p/i interface, whereas causing no light induced degradation.

It has been also observed that the initial incubation phase of nanocrystalline silicon growth has a deleterious effect on the Voc. A profiled layer, by using a continuous grading of hydrogen dilution or tailoring the initial $\mathrm{SiH}_{4}$ flow to circumvent the initial transient silane depletion, especially for low hydrogen dilution conditions, can deliver a much improved Voc. Combining a buffer layer with a profiled $\mathrm{SiH}_{4}$ flow, a Voc of $0.6 \mathrm{~V}$ has been crossed [38]. Without detailed defect density data, it is not certain whether the defects in the i-layer, especially at the interface or the incubation phase, control the Voc. The Voc is still $0.1 \mathrm{~V}$ lower than that of the c-Si cells. 


\subsection{Optical confinement}

Thin film amorphous and nanocrystalline silicon cells enjoy the advantage of higher light absorption compared to c-Si cells due to total or partial relaxation of the k-selection. However, the minimum defect density that can be obtained in these materials puts a limitation on the thickness that can be allowed for the best functioning of a cell and this thickness turns out to be considerably smaller than the absorption depth of white light (solar spectrum) in these materials. This is particularly important for the case of nc-Si in which case a rather thicker i-layer ( $>5 \mu \mathrm{m}$ on a flat cell) is needed compared to a-Si, both having similar defect densities of $\sim 10^{15} \mathrm{~cm}^{-3}$ in the best case [29]. Hence, to keep a high field inside the cell, in reality, a much thinner layer is used by taking the benefit of light trapping. The second reason is the long deposition time needed to make thick layers and this has a consequence on the throughput or particularly, in case of roll-to-roll process, the belt size. The deposition rate thus has become a major research issue and a number of innovations are taking place to achieve high rates. However, as we see in Fig. 6. Later in this paper, the effort is limited by the quality of the nc-Si material at high deposition rates. Hence, a support from light trapping allows a compromise on the thickness. This is basically achieved in three ways: (i) scattering of light travelling through rough instead of flat interfaces, (ii) metal reflector at the back side, and (iii) the light being trapped in a high refractive medium (refractive index $n \sim 4$ for $\mathrm{Si}$ ) sandwiched by low refractive index media ( $n \sim 2$ for TCO).

The rough interfaces are used in both $\mathrm{p}-\mathrm{i}-\mathrm{n}$ as well as $n-i-p$ structures, however, the details of their evolution at various interfaces of a cell are different for these two cases. Whereas for the $\mathrm{p}-\mathrm{i}-\mathrm{n}$ case, the texture originates at the front side and this roughness carries through the successive interfaces up to the back side, with diminishing size, for the $n-i-p$ case the rough interface originates at the back side and the roughness carries through to the front side with diminishing size. This has a consequence on the coupling to plasmon resonance, in which case the $\mathrm{p}-\mathrm{i}-\mathrm{n}$ structure has an advantage. Two types of rough TCOs for superstrate type of solar cells are used at present, $\mathrm{SnO}_{2}: \mathrm{F}$ and $\mathrm{ZnO}: \mathrm{Al}$. The $\mathrm{SnO}_{2}: \mathrm{F}$ TCO is commercially available only on glass (the best being Asahi U-type TCO) substrates, whereas this type of textured TCO on flexible substrate is developed in-house by the solar cell manufacturers, such as Helianthos b.v [39]. The $\mathrm{SnO}_{2}: \mathrm{F}$ coated substrates are suitable for a nc-Si cell only if the TCO is coated with a protective buffer layer such as $\mathrm{ZnO}: \mathrm{Al}$ of $~ 10 \mathrm{~nm}$ [29]. The buffer layer can in addition help to improve the current in the cell if its refractive index is suitably chosen. $\mathrm{TiO}_{2}$ layers of $20 \mathrm{~nm}$ have shown such an improvement. However, the best results for nc-Si cell are obtained with texture etched $\mathrm{ZnO}: \mathrm{Al}$ substrates. A comparison between similar nc-Si cells on a texture etched $\mathrm{ZnO}: \mathrm{Al}$ substrate and a $\mathrm{ZnO}$ :Al protected Asahi U-type $\mathrm{SnO}_{2}: \mathrm{F}$ TCO showed that the former has better efficiency [29]. This can be attributed to the substrate texture effect on the structure of the nanocrystalline film. A current of more than $22 \mathrm{~mA} / \mathrm{cm}^{2}$ can be achieved in a thin film of $\sim 1.5 \mu \mathrm{m}$. This is predominantly due to scattering of light at the rough surfaces, which increases the effective path length of the light. The same scattering concept is used also for $n-i-p$ type of cell. The widely used method is to make rough Ag layers and deposit $\mathrm{ZnO}$ conformally over it to make the back reflector. In such a case, the scattering is predominantly at the back side near the metal/ZnO interface. This has a consequence on the optical loss by plasmons which will be described later in this section.

The substrate temperature during Ag deposition plays an important role on the roughness of the Ag layer (Fig. 7). The growth of Ag depends on the temperature zone (defined by $T_{\mathrm{s}} / T_{\mathrm{m}}$, where $T_{\mathrm{m}}$ is the melting point of $\mathrm{Ag} \sim 1234 \mathrm{~K}$ ) in which Ag grows [40]. Moreover, the features at the Ag surface are also determined by the thickness because of the inhomogeneous evolution of the grains. The consequence is that a high roughness is accompanied by larger lateral size of the features, which is undesirable if the feature size becomes larger than the effective wavelength of light in the film. In order to achieve efficient Mie scattering, an innovative idea of increasing roughness while limiting the lateral growth has been proposed [40]. Impurity inhibited growth accomplished by adding a small percentage of Al to the Ag target in a sputter deposition does this job (Fig. 7). However, a loss factor also comes into picture, i.e. absorption by surface

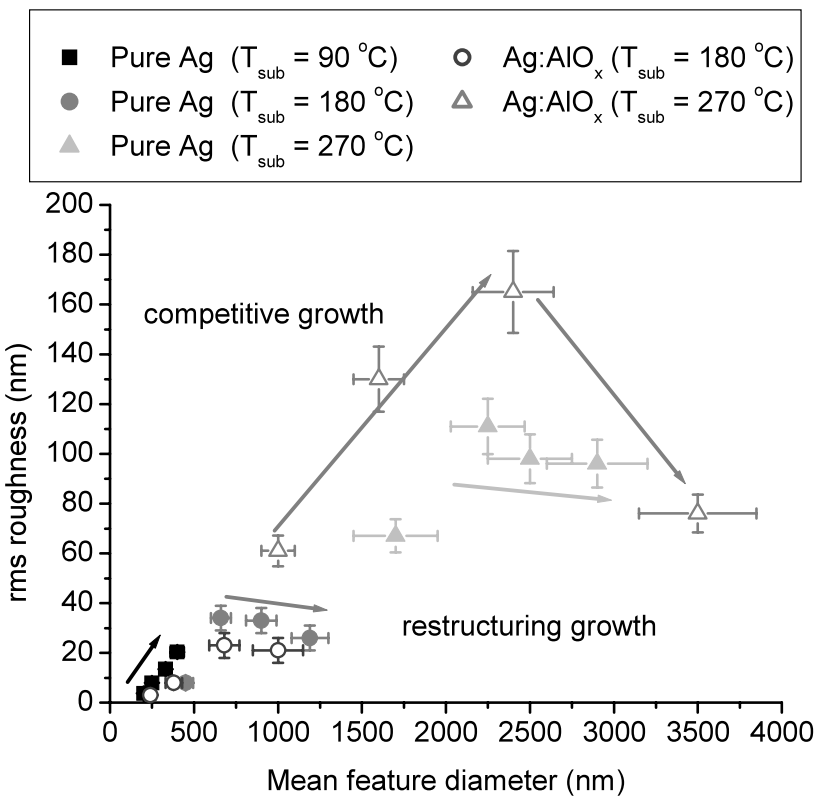

Fig. 7 The thickness evolution in rms roughness and feature diameter for 'pure' $\mathrm{Ag}$ and $\mathrm{Ag}: \mathrm{AlO}_{x}$ layers [40] 


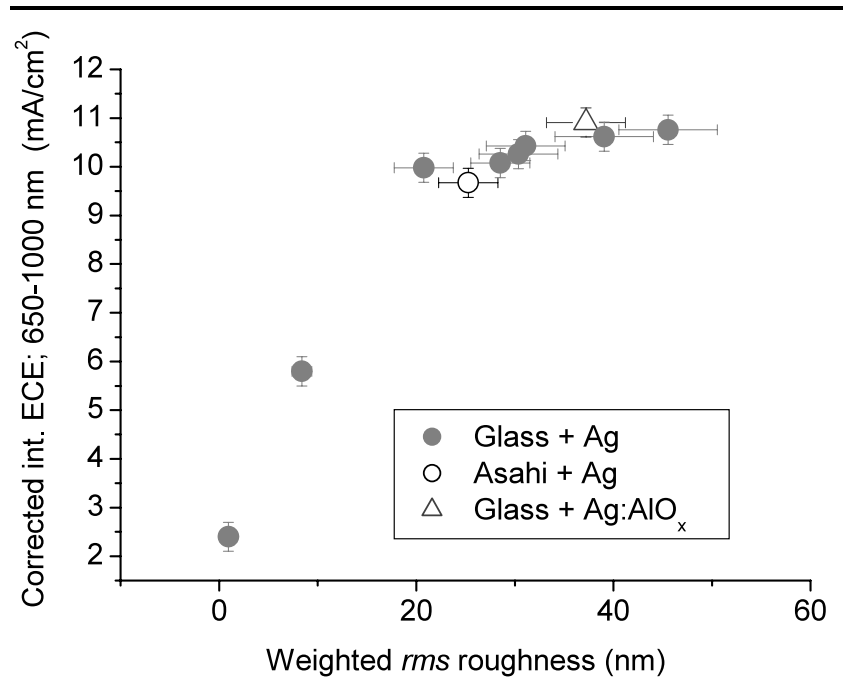

Fig. 8 The correlation between the weighted $r m s$ roughness values with the long wavelenght current density (integrated external collection efficiency) [43]

plasmons, which was first proposed by Springer et al. [41]. Plasmonic coupling at the $\mathrm{Ag} / \mathrm{ZnO}$ interface takes place basically by two mechanisms: (i) localised electron resonance in $\mathrm{Ag}$ protrusions and (2) surface plasmons associated with a plain metal surface. Initial reports suggest that the coupling of electromagnetic waves to the localised plasmons associated with the metal nanostructure leads to both dissipative as well as re-radiated scattering, whereas the coupling to the surface plasmons results in a loss only [42]. The total optical loss can be estimated from the reflectance at the interface. If this loss factor is taken into consideration in the calculation, a smooth relation (Fig. 8) between the current generated in a cell from the long wavelength part of the solar spectrum and the rms roughness of $\mathrm{Ag}$ is obtained [43]. An interesting observation is that a similar relation is obtained while correlating the current density with the integrated value of the angular resolved scattering (ARS) above 30 degrees.

\section{Conclusions}

The fabrication of nanocrystalline silicon cells (which is an essential component of "micromorph cells") by VHFPECVD at high deposition rate of more than $4 \mathrm{~nm} / \mathrm{s}$ for the i-layer with acceptable efficiencies has been demonstrated. This development makes the nanocrystalline material industrially attractive for thin film solar cell module fabrication. Record stabilised efficiencies have reached $10 \%$. Further increase of the deposition rate keeping an efficiency of $\sim 10 \%$ will be a technological challenge.

Open Access This article is distributed under the terms of the Creative Commons Attribution Noncommercial License which permits any noncommercial use, distribution, and reproduction in any medium, provided the original author(s) and source are credited.

\section{References}

1. T. Tomita, in Technical Digest of the International PVSEC-17, Fukuoka, Japan (2007), p. 1

2. Y. Tsunomura, Y. Yoshimine, M. Taguchi, T. Kinoshita, H. Kanno, H. Sakata, E. Maruyama, M. Tanaka, in Technical Digest of the International PVSEC-17, Fukuoka, Japan (2007), p. 387

3. M. Reuter, W. Brendle, O. Tobail, J.H. Werner, in Technical Digest of the International PVSEC-17, Fukuoka, Japan (2007), p. 424 ( $17 \%$ for 50 micron thick cell, transfer method)

4. G. Hahn, S. Seren, M. Kaes, A. Schönecker, J.P. Kalejs, C. Dubé, A. Grenko, C. Belouet, in Conference Record of the 2006 IEEE 4th World Conference on Photovoltaic Energy Conversion, WCPEC-4, vol. 1 (2007), p. 972

5. M. Gloeckler, in Technical Digest of the International PVSEC-17, Fukuoka, Japan (2007), p. 116

6. K. Matsunaga, T. Komaru, Y. Nakayama, T. Kume, Y. Suzuki, in Technical Digest of the International PVSEC-17, Fukuoka, Japan (2007), p. 455

7. M.A. Green, P.A. Basore, N. Chang, D. Clugston, R. Egan, R. Evans, D. Hogg, S. Jarnason, M. Keevers, P. Lasswell, J. O'Sullivan, U. Schubert, A. Turner, S.R. Wenham, T. Young, Sol. Energy 77, 857 (2004)

8. K. Yamamoto, A. Nakajima, M. Yoshimi, T. Sawada, S. Fukuda, T. Suezaki, M. Ichikawa, Y. Koi, M. Goto, T. Meguro, T. Matsuda, T.i Sasaki, Y. Tawada, in Conference Record of the 2006 IEEE 4th World Conference on Photovoltaic Energy Conversion, WCPEC-4, vol. 2 (2007), p. 1489

9. http://www.sharpnews.co.uk/?p=804

10. B. Yan, G. Yue, J.M. Owens, J. Yang, S. Guha, in Conference Record of the 2006 IEEE 4th World Conference on Photovoltaic Energy Conversion, WCPEC-4, vol. 2 (2007), p. 1461

11. J. Meier, S. Dubail, R. Flückiger, D. Fischer, H. Keppner, A. Shah, in Proceedings of First WCPEC (1994), p. 409

12. J.K. Rath, Sol. Energy Mater. Sol. Cells 76, 431 (2003)

13. C.A.M. Stap, H. Meiling, G. Landweer, J. Bezemer, W.F. van der Weg, in Proc. 9th EC Photovoltaic Solar Energy Conference, Freiburg (1989), p. 74

14. J.K. Rath, R.H.J. Franken, A. Gordijn, R.E.I. Schropp, W.J. Goedheer, J. Non-Cryst. Solids 338-340, 56 (2004)

15. J.K. Rath, L.A. Klerk, A. Gordijn, R.E.I. Schropp, Sol. Energy Mater. Sol. Cells 90, 3385 (2006)

16. J.K. Rath, A. Verkerk, M. Brinza, R.E.I. Schropp, W.J. Goedheer, V.V. Krzhizhanovskaya, Y.E. Gorbachev, K.E. Orlov, E.M. Khilkevitch, A.S. Smirnov, in 33rd IEEE PVSEC, San Diego (2008)

17. P.A.T.T. van Veenendaal, G.W.M. Mark, J.K. Rath, R.E.I. Schropp, Thin Solid Films 430(1-2), 41 (2003)

18. L. Guo, M. Kondo, M. Fukawa, K. Saitoh, A. Matsuda, Jpn. J. Appl. Phys. 37, L1116 (1998)

19. M. Heintze, R. Zedlitz, J. Non-Cryst. Solids 198-200, 1038 (1996)

20. A. Gordijn, M. Vanecek, W.J. Goedheer, J.K. Rath, R.E.I. Schropp, Jpn. J. Appl. Phys. 45, 6166 (2006)

21. A. Gordijn, J. Francke, L. Hodakova, J.K. Rath, R.E.I. Schropp, Mater. Res. Soc. Symp. Proc. 862, 87 (2005)

22. A. Gordijn, J.K. Rath, R.E.I. Schropp, in Technical Digest, Int. PVSEC15, Sanghai (2005), p. 955

23. J.K. Rath, F.D. Tichelaar, H. Meiling, R.E.I. Schropp, Mat. Res. Symp. Proc. 507, 879 (1998)

24. J.K. Rath, R.E.I. Schropp, W. Beyer, Diffus. Defect Data Part B: Solid State Phenom. 80-81, 109 (2001)

25. J.K. Rath, K.F. Feenstra, D. Ruff, H. Meiling, R.E.I. Schropp, Mater Res. Soc. Symp. Proc. 452, 977 (1997)

26. J.K. Rath, H. Meiling, R.E.I. Schropp, Jpn. J. Appl. Phys. 36, 5436 (1997) 
27. O. Vetterl, F. Finger, H. Wagner, Sol. Energy Mater. Sol. Cells 62, 97 (2000)

28. J. Meier, E. Vallat-Sauvain, S. Dubail, U. Kroll, J. Dubail, S. Golay, L. Feitknecht, P. Torres, S. Fay, D. Fiscjer, A. Shah, Sol. Energy Mater. Sol. Cells 66, 73 (2001)

29. A. Gordijn, J.K. Rath, R.E.I. Schropp, Prog. Photovolt.: Res. Appl. 14, 305 (2006)

30. Y. Mai, S. Klein, R. Carius, H. Stiebig, L. Houben, X. Geng, F. Finger, J. Non-Cryst. Solids 352, 1859 (2006)

31. C. Droz, E. Vallat-Sauvain, J. Bailat, L. Feitknecht, J. Meier, A. Shah, Sol. Energy Mater. Sol. Cells 81, 61 (2004)

32. J.H. Werner, K. Taretto, U. Rao, Solid State Phenom. 80-81, 299 (2001)

33. Y. Tsunomura, Y. Yoshimine, M. Taguchi, T. Kinoshita, H. Kanno, H. Sakata, E. Maruyama, M. Tanaka, in Technical Digest of the International PVSEC-17, Fukuoka, Japan (2007), p. 387

34. J. Meier, S. Dubail, J. Cuperus, U. Kroll, R. Platz, P. Torres, J.A. Anna Selvan, P. Pernet, N. Beck, N. Pellaton Vaucher, Ch. Hof, D. Fischer, H. Keppner, A. Shah, J. Non-Cryst. Solids 227-230, 1250 (1998)

35. J.K. Rath, A.J. Hardeman, C.H.M. van der Werf, P.A.T.T van Veenendaal, M.Y.S. Rusche, R.E.I. Schropp, Thin Solid Films 430(1-2), 67 (2003)
36. S. Klein, F. Finger, R. Carius, B. Rech, L. Houben, M. Luysberg, M. Stutzman, Mater. Res. Soc. Symp. Proc. 715, A26.2 (2002)

37. A. Gordijn, L. Hodakova, J.K. Rath, R.E.I. Schropp, J. Non-Cryst. Solids 352, 1868 (2006)

38. M.N. van den Donker, Plasma deposition of microcrystalline silicon solar cells: looking beyond the glass, Ph.D. Thesis, TU Eindhoven (2006)

39. J.K. Rath, Y. Liu, A. Borreman, E.A.G. Hamers, R. Schlatmann, G.J. Jongerden, R.E.I. Schropp, J. Non-Cryst. Solids 354(19-25), $2381(2008)$

40. R.H. Franken, R.L. Stolk, H. Li, C.H.M. van der Werf, J.K. Rath, R.E.I. Schropp, in 21st European Photovoltaic Solar Energy Conference, 4-8 September 2006, Dresden, Germany (2006), p. 1744

41. J. Springer, A. Poruba, L. Mullerova, M. Vanecek, O. Kluth, B. Rech, J. Appl. Phys. 95, 1427 (2004)

42. D. Sainju, P.J. van den Oever, N.J. Podraza, M. Syed, J.A. Stoke, J. Chen, X. Yang, X. Deng, R.W. Collins, in Proc. of the 4th World Conf. On Photovoltaic. Energy Conversion (IEEE, Piscataway, 2006), p. 1732

43. R.H. Franken, R.L. Stolk, H. Li, C.H.M. van der Werf, J.K. Rath, R.E.I. Schropp, in 21st European Photovoltaic Solar Energy Conference, 4-8 September 2006, Dresden, Germany (2006), p. 1565 